\title{
Ponderosa Pine Undergrowth Restoration on the Arizona Strip
}

\section{Logging and thinning the forest is a straight out deal. Its coming to a consensus on what the understory vegetation needs to be that gets sensitive.}

\section{By Lee E. Hughes}

$\mathrm{D}$ uring the early 1990's, the ponderosa pine ecosystem on the Arizona Strip was termed a forest in poor health by the Bureau of Land Management (BLM). This was largely due to the density of its trees (hundreds per acre).

The pre-settlement forest, which existed prior to European man settling in Arizona, had in general, 15-40 trees per acre with some patches of denser stands. The latest year fixed for this condition is 1870 , as determined from old photographs taken during the 1860 s to 1880 s in the ponderosa pine areas around Flagstaff, Arizona. Counting annual tree growth rings aided in establishing that date. This, pre-settlement forest density was corroborated by counting old growth stumps and snags on the Arizona Strip (See map).

Currently, the Arizona Strip has around 15,000 acres of ponderosa pine. Approximately, 12,000 acres of that is in the Mt. Trumbull/Mt. Logan area. Pre- settlement forests occupied, as best can be determined, about the same acreage. Critics claimed

\section{Arizona Strip District}

\section{Mt. Trumbull Resource Conservation Area}

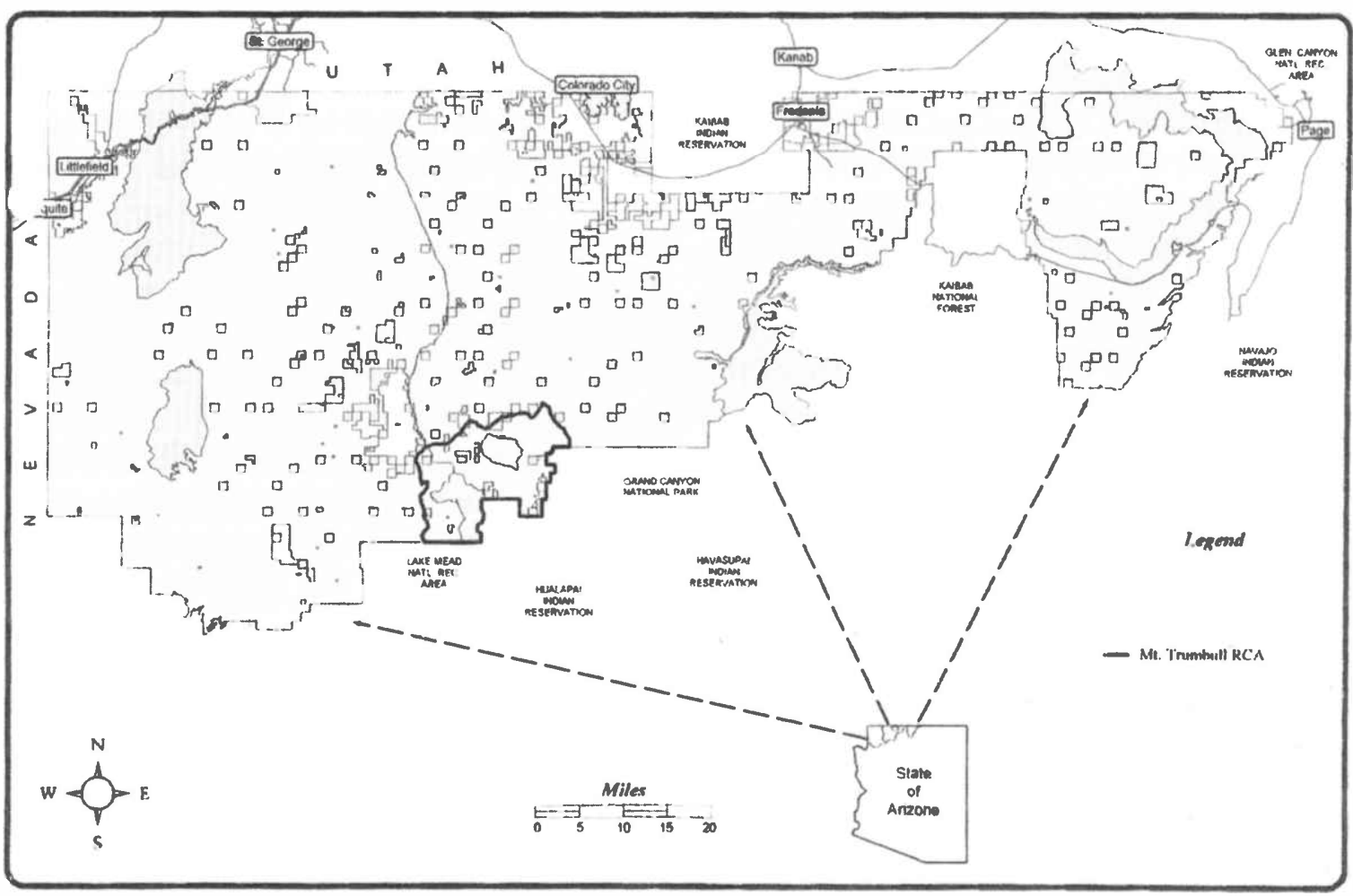


that the decline of the ponderosa pine ecosystem from the pre-settlement time period was largely due to livestock grazing, a lack of logging, and fire suppression efforts.

Regardless of the cause for the decline, the thick forest on the Arizona Strip was already at a high potential for disease and damaging wildfire. Consequently, there were forces to change management habits from within the BLM and by the public. A movement was implemented to balance the Mt. Trumbull/Mt. Logan forest size class/structure.

\section{Planning the Forest Structure}

The Arizona Strip Field Office developed a Resource Conservation Plan (RCA) for the Mt. Trumbull (includes Mt. Logan) area from 1993 to 1995 (See map). During development of the plan, objectives were designed to describe quantitatively the diameter size of trees/structure stages desired for the Mt. Trumbull/Mt. Logan forests. From initial inventories the size class/structure of the Mt. Logan forest showed a large quantity of small trees $-90 \%$ with a $1-19 "$ diameter at breast height (dbh) size class. Only $6 \%$ of the forest had areas dominated by 20 " dbh trees or larger size class.

Six tree size diameter classes /structure stages were described in the RCA plan ranging from: openings or meadows, seedling/sapling (1-5" dbh), young trees (5-12" dbh), middle-aged trees (12-20" $\mathrm{dbh})$, mature trees (20-24" dbh), and old-growth trees (24"+ at dbh).

The Mt Trumbull interdisciplinary team, which involved BLM, Arizona Fish and Game, affected citizens, and academia, came to a consensus that the Mt. Trumbull landscape would be healthiest and meet multipe use objectives, at $50 \%$ old-growth trees $(20-32 "+\mathrm{dbh})$ and the remaining $50 \%$ of the forest needed to consist of openings and of trees up to middle age (12-20" dbh).

\section{Getting There by Prescription}

Early in 1995, Dr. Wallace Covington and a restoration team from the Northern Arizona University (NAU) Ecological Restoration Institute (ERI) visited the Arizona Strip and began a process to provide the BLM with a tree-density, prescription to restore the Mt. Logan forest to its 1870 density levels (15-40 trees per acre). The 1870 level was just prior to European settlements with the fire sup- pression efforts and livestock grazing.

One of the first steps was to identify spacing of the trees to pre-settlement levels. The process of marking trees to leave began by locating evidence of dead, old-growth trees such as cut stumps and snags. Most were easily found, but on occasion, remnants were merely a woody outline on the ground or a portion of a log. For each old growth stump, snag, or remnant of old growth, one and half leave trees were marked. In other words, two leave trees were marked one time and the next stump had one leave tree marked. That process was then repeated. The leave tree was the tree left after logging and thinning. The leave tree had to be greater than 16 inches in dbh.

If only smaller trees were available, three times as many trees were marked. More smaller ones were marked due to their higher mortality from the postthinning prescribed fire. This then left the desired amount of trees needed as replacements after the restoration. All existing old-growth-yellow-bark ponderosa were marked as leave trees.

The first marking of leave trees started in the fall of 1995. Two small units (both are designated Lava or 96-1) were marked and cruised (volume of timber estimated in board feet) and readied for harvest. One unit was 13 acres and the other 33 acres. They were both commercially logged, after which postcommercial thinning was done. Post-commerical thinning occurred where small trees were left uncut by the logger. Thinning involved cutting the small trees. The slash from the thinning was then burned and the 13-acre unit was seeded. The 33-acre unit was not seeded - in order to compare unseeded to seeded understory. This completed the restoration effort for the units.

At the same time, the NAU team established fire monitoring plots to monitor vegetation and fuels The plots were laid out in a 300 yard grid pattern across Mt. Logan's entire 8,500 acres of ponderosa forest. The study was to demonstrate the non-treatment, pre-treatment and post-treatment impacts to vegetation. Other studies on wildlife were established to study the effects of restoration on wildlife populations.

\section{Planning the Understory Vegetation}

No vegetation objectives were set for the ponderosa pine understory in the 1993-1995 planning 
Table 1. Vegetation trend plot data lava unit plots frequency data.

\begin{tabular}{|c|c|c|c|c|c|c|c|c|c|}
\hline \multirow[t]{2}{*}{ SPECIES } & \multicolumn{3}{|c|}{$\begin{array}{l}\text { Lava Unit 96-1 Seeded } \\
13 \text { acre one plot } \\
\text { \% Occurence }\end{array}$} & \multicolumn{6}{|c|}{ Lava 96-1 Unseeded 33 acres two plots } \\
\hline & $1995^{*}$ & 1997 & 2001 & 1995 & 1997 & 2001 & 1995 & 1997 & 2001 \\
\hline $\begin{array}{l}\text { Native Perennial } \\
\text { (Squirrel tail } \\
\text { Blue Grama } \\
\text { Muttongrass) }\end{array}$ & $\begin{array}{l}(\%) \\
13\end{array}$ & $\begin{array}{c}(\%) \\
2\end{array}$ & $\begin{array}{c}(\%) \\
4\end{array}$ & $\begin{array}{c}(\%) \\
6\end{array}$ & $\begin{array}{c}(\%) \\
9\end{array}$ & $\begin{array}{c}(\%) \\
41\end{array}$ & $\begin{array}{c}\%) \\
8\end{array}$ & $\begin{array}{c}\%) \\
10\end{array}$ & $\begin{array}{c}(\%) \\
19\end{array}$ \\
\hline $\begin{array}{l}\text { Seeded } \\
\text { (Wheatgrasses } \\
\text { Mtn Brome } \\
\text { Junegrass) }\end{array}$ & 0 & 3 & 62 & 0 & 0 & 0 & 0 & 0 & \\
\hline $\begin{array}{l}\text { Forbs } \\
\text { (Horseweed } \\
\text { Chenopods } \\
\text { Mullein } \\
\text { Etc) }\end{array}$ & 9 & 7 & 108 & 7 & 33 & 33 & 8 & 31 & 44 \\
\hline $\begin{array}{l}\text { Shrubs } \\
\text { (Locust) } \\
\text { Browse } \\
\text { Cheatgrass }\end{array}$ & 15 & 0 & 0 & 7 & 33 & 33 & 8 & 31 & 44 \\
\hline Cheatgrass & 4 & 0 & 11 & 0 & 1 & 0 & 4 & 0 & 3 \\
\hline $\begin{array}{l}\text { Percent Native to } \\
\text { Non-Native }\end{array}$ & 88:15 & 100:0 & $80: 20$ & $95: 5$ & $97: 3$ & 93:7 & 69:31 & $92: 8$ & 98:2 \\
\hline
\end{tabular}

The vegetation inventories provided information of understory characteristics. The 1996 NAU pretreatment inventory of the ponderosa pine in the Lava Units (the 13 and 33 acre units) showed the top four understory species in frequency were big sage, squirreltail, silver lupine and cheatgrass. New Mexico locust, beardlip penstemon, and mullein were present but less common (See Table 1).

Seed bank studies were conducted in the late 1990s in a subset of plant communities on Mt. Logan by Judy Springer of NAU. She found that early successional and non-native forbs dominated the seed bank, whereas seeds of shrubs and perennial grasses were scarce. In ponderosa pine plant communities (old-growth and pole-size) bottlebrush squirrel-tail, a native, had a presence in the seed bank. Mullein and horseweed, however, were the dominant viable seeds by a large margin in the seed-bank. The seedbank and extant vegetation proved to be the best predictor of what the restored plant community would have as vegetation cover in the first few years after treatment.

\section{SIDEBAR TO TABLE 1 \\ Vegetation Frequency Trend Protocol \\ Across the landscape a grid was established of plots. The plots were 300 meters apart. Each plot is 50X20 meters. Inside the plots herbaceous plants are counted in two point intercept transects. Each transect has 166 points along each 50 meter side of the inside the plot. Outside the plot on both 50 meter sides is a belt transect of 10 meter by 50 meter and all species are list- ed that occur within the two belt transects. The data above is from the belt transects.}

\section{Seeding}

As a result of the inventories and seed-bank studies, seeding of native grasses appeared necessary for perennial grass diversity. Fifteen species of perennial grass were seeded in designated-to-beseeded units. Eight species of perennial forbs and five species of shrubs were seeded one time only, due to high cost ( $\$ 15$ to $\$ 82$ per pound). The seeded Lava Unit (13 acres) had to be reseeded the following year, as the first seeding failed to survive a drought.

Four experimental units, that have been restored outside the Lava units on Mt Logan, were not seeded. This was done to determine the kind of under- 
Table 2. Cost per acre of seeding on other units.

\begin{tabular}{|l|c|c|c|c|c|}
\hline \hline Year Seeded & $\begin{array}{c}\text { Logged } \\
\text { Unit }\end{array}$ & Seeded & Seed & $\begin{array}{c}\text { Labor } / \\
\text { Equipment }\end{array}$ & $\begin{array}{c}\text { Total } \\
\text { Cost }\end{array}$ \\
\hline 1997 & $96-1$ & $\begin{array}{c}\text { (acres) } \\
13\end{array}$ & $\begin{array}{c}(\$ / a c) \\
\$ 214\end{array}$ & $\begin{array}{c}\text { (\$/ac) } \\
\text { Not figured }\end{array}$ & $(\$ / a c)$ \\
1998 & $96-1$ & 13 & $\$ 228$ & & \\
1998 & $96-2$ & 156 & $\$ 73$ & $\$ 34$ & $\$ 107$ \\
1999 & $96-2$ & 80 & $\$ 79$ & $\$ 38$ & $\$ 117$ \\
2000 & $96-3$ & 110 & $\$ 103$ & $\$ 38$ & $\$ 141$ \\
\hline
\end{tabular}

story plant community that would result after different year intervals in these restored units.

Inventories have shown that in old wildfire burns, grasses such as squirrel tail, blue grama, and mutton grass have come in vigorously and abundantly in some locales in the ponderosa zone, without seeding. In 1989, a 78 acre fire occurred on the top of Mt Trumbull (a Wilderness Area). Weight transects, where vegetation is clipped and weighed at points along the transect to determine species composition by weight, were done in 1992 and 2001 in the fire scar and adjacent unburned forest. The transects in the fire scar had a range of $23-42 \%$ squirrel tail and $16-35 \%$ oak with 18 other species weighing in at much lesser rates. The adjacent unburned forest had trace amounts of squirrel tail with upland sedge oc- curring at up to $24 \%$. Few other species occurred under the pine.

\section{Cost of Going Native}

Table 2 summarizes the cost of seeding in the first restoration units treated. The costs were high due to using the expensive forbs and shrubs along with the native grasses. The forbs and shrubs ranged in price from $\$ 15$ to $\$ 82$ a pound, with most in the $\$ 40$ to $\$ 60$ per pound range. Native grass costs ranged from about $\$ 1$ to $\$ 40$ per pound with most in the range of $\$ 5$ to $\$ 20$ per pound. The costs shown in Table 2 are seed costs, the labor and operating equipment costs only. All seeding was done by using hand powered broadcasters and dragging the area after seeding with all-terrain-vehicles pulling small chains. The seeded and unseeded Units were fenced with an electric fence to prevent livestock from grazing the forage prior to good establishment. (See Photos 1 \& 2).

\section{The Outcome}

The forest diameter size class/structure objective of $50 \%$ old growth and $50 \%$ smaller trees and openings, in the higher elevation units were close to being met after the logging, thinning and burning.

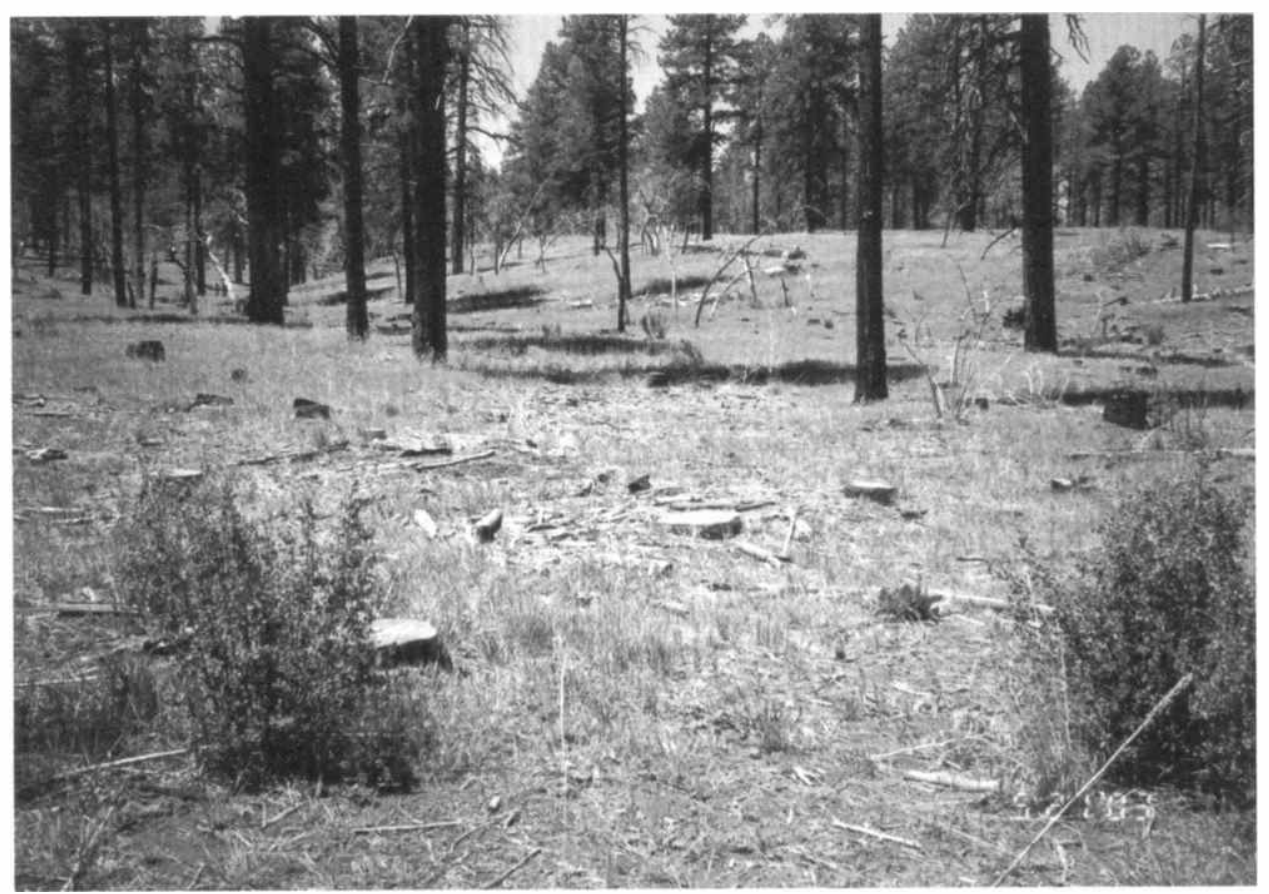

This picture is of the Lava Unit six years after being logged, burned and seeded. The seeded grasses can be seen in the foreground. The numerous stumps in the foreground demonstrate how dense the trees were. 


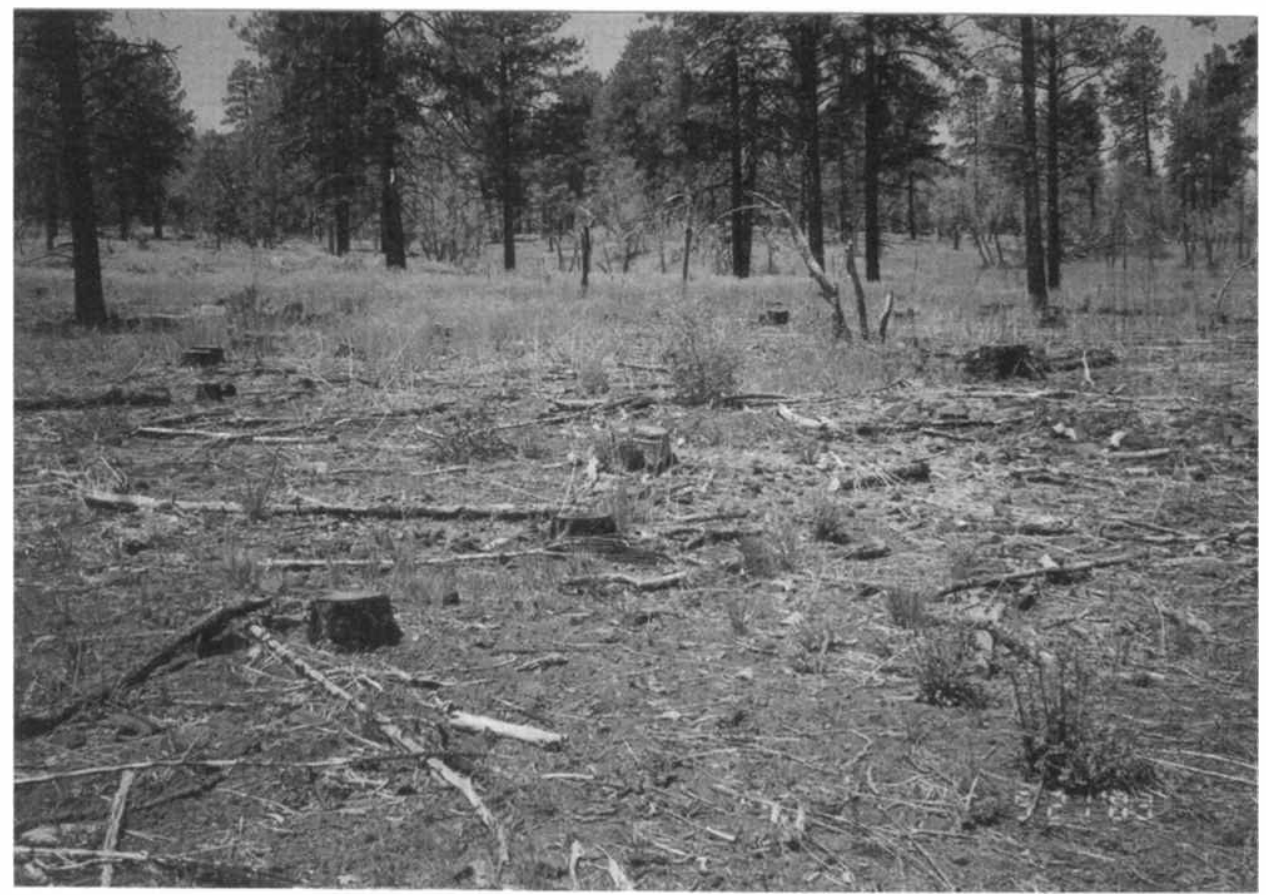

This is the unseeded Lava Unit (33 acres) after six years thinning and burning. Some native grasses can be seen in the foreground. Overall, there is little differences between the two units as yet.

Reaching stability on the forest floor, however, will take longer, even with seeding, due to successional processes.

Seeding native grasses, shrubs and forbs greatly added grass diversity and cost in the seeded unit. Five years after seeding took place, the understory definitely became co-dominated by seeded grasses (See Table 1). But forbs and non-native forbs still were dominant and abundant in the seeded unit. The unseeded under-stories were dominated by shrubs, annuals, and forbs with less diversity of grasses. Is the seeded native grass diversity worth the cost? Could the understory restoration still be considered restoration with the species that are already present such as blue grama, squirrel-tail, mutton-grass and the numerous native forbs and shrubs shown in the inventories?

The resulting vegetation after logging, post-commercial thinning and burning, has not resulted in a total take over, as yet, by non-native weeds, which was of some concern. As Table 1 shows its other natives that remain in dominance.
With rest-rotation grazing and rest from grazing, and maturing of the plant community after treatment, over the years, a stable plant community would probably result without expensive seeding or at least a reduced amount of seeding. Needed seeding can be ascertained and could be done at a later date, for example, after one of the repeat burns which are part of the future in the restoration plan at five year intervals or as needed to keep tree densities low.

\footnotetext{
About the Author:

The author is an Ecologist from the Bureau of Land Management on the Arizona Strip Field Office, where he has been stationed since 1977.
} 